\title{
The Legal Protection Against Children Who Did Criminal Actions Through Diversion
}

\author{
Masngud Afandi*) and Gunarto**) \\ *) Master of Law Program, Faculty of Law Universitas Islam Sultan Agung email \\ masngudafandi58@gmail.com \\ **) Faculty of Law, Universitas Islam Sultan Agung
}

\begin{abstract}
The purpose of this study is to examine and analyze the legal protection of children who commit crimes through diversion in terms of the juvenile criminal justice system. This study uses a normative juridical approach. Based on the research, it is concluded that children dealing with the law are considered as legal subjects who are not yet competent and cannot understand what they are doing. Investigation of children's cases is carried out by investigators determined by the Decree of the Head of the State Police of the Republic of Indonesia or other officials appointed by the Head of the State Police of the Republic of Indonesia. On the other hand, if the Diversion process fails, the Investigator is obliged to continue the investigation and delegate the case to the Public Prosecutor by attaching the diversion report and the community research report. Arrested children must be deposited in LPKS. The cost for each child placed in LPKS is charged to the budget of the ministry that carries out government affairs in the social sector.

Keywords: Legal Protection; Diversion; Juvenile Justice System.
\end{abstract}

\section{Introduction}

The Unitary State of the Republic of Indonesia is one of the big countries that prioritizes the applicable legal provisions. The positive rule of law that applies in Indonesia is clearly an important component in building a safe, peaceful and peaceful life. ${ }^{1}$ As in the Constitution of the Republic of Indonesia, namely the 1945 Constitution of the Republic of Indonesia, which has confirmed that Indonesia is a state of law, this phrase is contained in Article 1 paragraph 3 of the 1945 Constitution of the Republic of Indonesia. ${ }^{2}$ This emphasizes that the implementation of the Indonesian state government must always be based on and in accordance with the will of the law. The fourth paragraph of the Preamble to the 1945 Constitution which is the constitutional basis of this country states that one of the goals of the state is to create general welfare and educate the nation's life. ${ }^{3}$ This has the implication that public welfare is a constitutional ideal, accompanied

\footnotetext{
${ }^{1}$ Sumaryono and Sri Kusriyah, The Criminal Enforcement of the Fraud Mode of Multiple Money (Case study Decision No.61 / Pid.B / 2019 / PN.Blora) Jurnal Daulat Hukum: Volume 3 Issue 1, March 2020, url: http://jurnal.unissula.ac.id/index.php/RH/article/view/8811/4075

2 Majelis Permusyawaratan Rakyat Indonesia, Undang-Undang Dasar Negara Republik Indonesia tahun 1945, Jakarta: Sekretariat Jenderal MPR RI, 2015, p. 116.

${ }^{3}$ Sulistiyawan Doni Ardiyanto, Eko Soponyono, and Achmad Sulchan, Judgment Considerations Policy in Decree of the Court Criminal Statement Based On Criminal Destination, Jurnal Daulat Hukum: Volume 3 Issue 1, March 2020, url:
} http://jurnal.unissula.ac.id/index.php/RH/article/view/8409/4067 
by the growth of an intelligent Indonesian people who are able to lead the Indonesian nation as a sovereign and prosperous country.

In addition to the rule of law, Indonesia is also a country that upholds human rights, including the rights of children, which is marked by the guarantee of protection and fulfillment of children's rights in the 1945 Constitution of the Republic of Indonesia and several provisions of laws and regulations both national and international. ${ }^{4}$ The concrete form of the Government in providing protection to everyone, especially to children as regulated in Article 28D paragraph (1) of the 1945 Constitution of the Republic of Indonesia, namely "Everyone has the right to recognition, guarantee, protection, and fair legal certainty and equal treatment before the law" and Article 28B paragraph (2) of the 1945 Constitution of the Republic of Indonesia, namely "Every child has the right to survive, grow, and develop and has the right to protection from violence and discrimination".

Along with the development of the era of child delinquency has entered a very worrying threshold. Romli Atmasasmita, as quoted by Wagiati Soetodjo, argues that juvenile delinquency is "every act or behavior of a child under the age of 18 and unmarried which is a violation of applicable legal norms and can endanger the child's personal development ${ }^{5}$ Along with the development of the times, it is very impossible for a child to commit a crime, and nowadays it is very common for criminal acts to appear committed by a child who is still under age, such as theft, rape, and even murder.

Every year children who become perpetrators of criminal acts always increase, in certain cases, children who become perpetrators are of special concern to law enforcement officers. Therefore, various prevention and control efforts against children in conflict with the law need to be carried out immediately. One of efforts to prevent and deal with children who are in conflict with the law today are through the implementation of the juvenile criminal justice system. ${ }^{6}$

UNICEF estimates that more than 1 million children are behind bars worldwide. ${ }^{7}$ During later processes in the juvenile justice system, harmful effects can arise, such as the stigmatization of criminal penalties. Children as perpetrators of criminal acts will be labeled as criminal criminals with lifelong dimensions. Not only that, child offenders will have the potential to increase the number of criminal offenders in the future.

Indeed, as children grow, they are often influenced by the social environment in which they hang out and socialize. Not infrequently initially of

\footnotetext{
${ }^{4}$ Ari Yudistira and Widayati, The Investigation Process of Prospective Children in Criminal Action, Jurnal Daulat Hukum: Volume 4 Issue 1, March 2021, url:http://jurnal.unissula.ac.id/index.php/RH/article/view/13695/5374

${ }^{5}$ Wagiati Soetedjo dan Melani, Hukum Pidana Anak, Bandung: Refika Adhitama, 2013, p.11

${ }^{6}$ Didi Wahyudi Sunansyah, and Aryani Wirasari, Effectiveness Of Allotment Penalty Imposed By Judge In The Case Of Children For A Child Protection As Victims(Case Study at State Court of Sumber), Jurnal Daulat Hukum: Volume 3 Issue 1, March 2020, url: http://jurnal.unissula.ac.id/index.php/RH/article/view/8483/3939

${ }^{7}$ Mohammad Farid Fad, Analisis Model Diversi Melalui Restorative Justice Pada Anak Pelaku Tindak Pidana Terorisme Dalam Perspektif Maqashid Syariah, UIN Walisongo Semarang, Al-Daulah, Vol.9 No.1, April 2009, p. 53
} 
good character, but due to exposure to the influence of associates, they turn naughty, even committing deviant behavior that can be categorized as a crime. In the end, he will be faced with a legal process that is too heavy for his age. Theoretically, a child in conflict with the law is defined as someone under the age of 18 who is dealing with the criminal justice system because the person concerned is suspected or accused of committing a crime.

The renewal of the criminal law of children in criminal policies is an integral part of efforts to protect society and achieve community welfare. The criminal policy of using penal facilities in Indonesia is embodied in Act No. 11 of 2012 concerning the juvenile criminal justice system which must prioritize a restorative justice approach, namely diversion. In the implementation of juvenile criminal justice, there is a fact that criminal court proceedings for children have a negative impact on children. Imprisonment for children shows a tendency to be detrimental to mental development. Currently, the majority of children are in conflict with the law, especially those brought to the criminal justice system. If children are in prison, many of their rights guaranteed by the Child Protection Act are not fulfilled. ${ }^{8}$

The transfer of the juvenile justice process or what is called diversion is useful to avoid the negative effects of subsequent judicial processes in the administration of juvenile justice, for example labeling due to a guilty statement or sentencing. In carrying out diversion against children in conflict with the law, the Police Investigators actually have a legal umbrella based on the laws and regulations that authorize such actions as well as implementing guidelines in the Internal Police.

Based on the description above, this study aims to examine and analyze the legal protection of children who commit crimes through diversion in terms of the juvenile criminal justice system.

\section{Research Methods}

This study uses a normative juridical method, with a descriptive analytical research specification. The type of data used in this study is secondary data, namely: covering primary legal materials, secondary legal materials and tertiary legal materials. The data collection technique in this research is literature study. After the data from the field was collected using the data collection method described above, it was analyzed using qualitative descriptive analysis. The data analysis used in this research is qualitative data analysis.

\section{Results and Discussion}

The word Diversion comes from the English word "Diversion", which is a term for diversion, because it is based on the improved Indonesian Spelling General Guidelines and General Guidelines for the Formation of Terms, adjusting the endings -sion, -tion to -si. Therefore, the word diversion in Indonesia becomes

\footnotetext{
${ }^{8}$ Setya Wahyudi, Implementasi Ide Diversi dalam Pembaruan Sistem Peradilan Pidana Anak di Indonesia, Yogyakarta: Genta Publishing, 2011, p. 3.
} 
diversion. Diversion is the granting of authority to law enforcement officers to take policy actions in dealing with or resolving the problem of child offenders by not taking formal steps, including stopping or not continuing or releasing from the criminal justice process or returning or submitting to the community and other forms of diversion. Other forms of social service activities. The application of diversion can be carried out at all levels of examination.

The implementation of the concept of diversion is carried out with the aim of preventing children from the negative implications of the existing criminal justice system, preventing children from entering the juvenile criminal justice system and eliminating the label of criminals against children who have already become victims of the system and the development of the existing social environment. The concept of diversion is developed in almost all countries, because this concept of diversion shows the success in saving and providing protection for children. ${ }^{9}$

Special protection for children in conflict with the law is carried out through; humane treatment by taking into account the needs according to their age; separation from adults; the effective provision of legal and other assistance; implementation of recreational activities; release from torture, punishment, or other cruel, inhuman and degrading treatment of dignity and status; avoidance of imposition of capital punishment and/or life imprisonment; avoidance of arrest, detention or imprisonment, except as a last resort and for the shortest time; providing justice before a juvenile court that is objective, impartial, and in a trial closed to the public; avoidance of publication of his/her identity; providing assistance to parents/guardians and people who are trusted by the child; providing social advocacy; giving of personal life; providing accessibility, especially for children with disabilities; providing education; provision of health services; and granting other rights in accordance with the provisions of laws and regulations. ${ }^{10}$

Article 18 of Act No. 23 of 2002 states that every child who is a victim or perpetrator of a crime has the right to get legal assistance and other assistance. In the explanation section of Act No. 23 of 2002 it is said, other assistance in this provision includes medical, social, rehabilitation, vocational and educational assistance. Every case that goes to the police, if the perpetrator has not been accompanied by a legal counsel, the RPK Polda team is obliged to report it to the Child Legal Aid Institute, so that children who are perpetrators or victims of criminal acts can receive legal assistance and assistance.

The juvenile court process will be carried out differently from the ordinary court process. In each trial the panel of judges will be present as mediators and advisers, without using the judge's uniform and other attributes. This is done to maintain the emotional and psychological stability of the child. With this condition, the child does not feel that he is the worst person and is very guilty.

${ }^{9}$ R. Wiyono, Sistem Peradilan Pidana Anak di Indonesia, Jakarta: Sinar Grafika, 2016, p. 47

${ }^{10}$ Yati Sharfina Desiandri, Diversi Terhadap Anak yang Berkonflik dengan Hukum di Tingkat Penyidikan,USU Law Journal, Vol. 5 No. 1, January 2017, p. 147-157 
A child in conflict with the law is a child who is involved in legal problems or as a criminal, while the child is not yet considered capable of being responsible for his actions, considering that he is not yet an adult and is growing and developing, so he has the right to be protected in accordance with the law. . Children who are not yet 14 years old can only be subject to action.

Children in Conflict with the Law are considered as legal subjects who are not yet competent and cannot understand what they are doing. However, in the era of globalization as it is today, the formation of children's character and mindset is strongly influenced by the environment, whether they are socializing or other things that are easily obtained through information media, both electronically and non-electronically. Thus, a criminal act committed by the $\mathrm{ABH}$ may indeed be desired by the $\mathrm{ABH}$ and he also understands what the consequences of his actions are. If the crime committed by the child carries a penalty of less than 7 years and a diversion is carried out against him, it is feared that it will not have a deterrent effect and the ABH will do it again.

Investigation of children's cases is carried out by investigators who are determined based on the Decree of the Head of the Indonesian National Police or other officials appointed by the Head of the Indonesian National Police. On the other hand, if the Diversion process fails, the Investigator is obliged to continue the investigation and delegate the case to the Public Prosecutor by attaching the diversion report and the community research report.

Children who are arrested must be deposited in the LPKS. The cost for each child placed in LPKS is charged to the budget of the ministry that carries out government affairs in the social sector. Detention of a Child can only be carried out with the following conditions:

- The child is 14 (fourteen) years old or more;

- Suspected of committing a crime with a threat of imprisonment of 7 (seven) years or more.

Prosecution of children's cases is carried out by the Public Prosecutor who is determined based on the decision of the Attorney General or other officials appointed by the Attorney General. The requirements for being a Public Prosecutor are as follows:

- Has experience as a public prosecutor;

- Have interest, attention, dedication, and understand the problem of the Child;

- Has attended technical training on juvenile justice.

The prosecution task is carried out by the public prosecutor who carries out the task of prosecuting criminal acts committed by adults. In the Diversion process where an agreement is reached, the Public Prosecutor submits the minutes of the Diversion along with the Diversion agreement to the head of the district court to make a determination. In the failed Diversion process, the Public Prosecutor is obliged to submit an official report on the Diversion and delegate the case to the court by attaching a report on the results of community research. ${ }^{11}$

\footnotetext{
${ }^{11}$ Dwidja Priyatno, Wajah Hukum Pidana Asas dan Perkembangan, Bekasi: Gramata Publishing, 2012, p. 308
} 
The Juvenile Criminal Justice System is all elements of the criminal justice system related to handling cases of ABH (Children with Problems with the Law). Police, Prosecutors and Courts as well as community advisors or Correctional Centers, advocates or aid providers, Child Special Guidance Institutions (LPKA), Temporary Child Placement Institutions (LPAS), and Social Welfare Implementation Institutions (LPKS) as institutions or institutions that handle ABH starting from The child is in contact with the justice system, determining whether the child will be placed in choices ranging from being released to being included in a sentencing institution in the corridor of restorative justice.

Punishment for perpetrators of child crimes does not then achieve justice for the victims, considering that from the other side it still leaves its own problems that are not resolved even though the perpetrators have been punished. Seeing the principles regarding child protection, especially the principle of prioritizing the best interests of the child, a process for resolving child cases is needed outside the criminal mechanism or commonly called Diversion. Punishment institutions are not a way to solve children's problems because they are prone to violations of children's rights. Therefore we need an event and procedure in the system that can accommodate the settlement of cases, one of which is by using a restorative justice approach,

One form of the restorative justice mechanism is dialogue among the Indonesian people, better known as "deliberation for consensus". So that diversion, especially through the concept of restorative justice, becomes a very important consideration in resolving criminal cases committed by children.

\section{Closing}

Children in Conflict with the Law are considered as legal subjects who are not yet competent and cannot understand what they are doing. However, in the era of globalization as it is today, the formation of children's character and mindset is strongly influenced by the environment, whether they are socializing or other things that are easily obtained through information media, both electronically and non-electronically. Thus, a criminal act committed by the ABH may indeed be desired by the $\mathrm{ABH}$ and he also understands what the consequences of his actions are. If the crime committed by the child carries a penalty of less than 7 years and a diversion is carried out against him, it is feared that it will not have a deterrent effect and the $\mathrm{ABH}$ will do it again. The police and the community must synergize and build the same perception about diversion and restorative justice efforts. Diversion efforts aim to provide an alternative settlement of a case against a child as a criminal, so that between the victim, the perpetrator, the victim's family, the perpetrator's family and the community, law enforcement officials, especially the Child Public Prosecutor, are given the same understanding and interests of child offenders. So that not only pay attention to the rights of victims to be protected, but also the rights of children as perpetrators can be truly protected. Parents must participate in providing protection for children by fulfilling children's rights, protect the interests of children and further enhance supervision of the environment and where children play. 


\section{References}

\section{Journal}

[1] Ari Yudistira and Widayati, The Investigation Process of Prospective Children in Criminal Action, Jurnal Daulat Hukum: Volume 4 Issue 1, March 2021, url:http://jurnal.unissula.ac.id/index.php/RH/article/view/13695/5374

[2] Didi Wahyudi Sunansyah, and Aryani Wirasari, Effectiveness Of Allotment Penalty Imposed By Judge In The Case Of Children For A Child Protection As Victims(Case Study at State Court of Sumber), Jurnal Daulat Hukum: Volume 3 Issue 1 , March 2020, url: http://jurnal.unissula.ac.id/index.php/RH/article/view/8483/3939

[3] Mohammad Farid Fad, Analisis Model Diversi Melalui Restorative Justice Pada Anak Pelaku Tindak Pidana Terorisme Dalam Perspektif Maqashid Syariah, UIN Walisongo Semarang, Al-Daulah, Vol.9 No.1, April 2

[4] Setya Wahyudi, Implementasi Ide Diversi dalam Pembaruan Sistem Peradilan Pidana Anak di Indonesia, Yogyakarta: Genta Publishing, 2011

[5] Sulistiyawan Doni Ardiyanto, Eko Soponyono, and Achmad Sulchan, Judgment Considerations Policy in Decree of the Court Criminal Statement Based On Criminal Destination, Jurnal Daulat Hukum: Volume 3 Issue 1, March 2020, url: http://jurnal.unissula.ac.id/index.php/RH/article/view/8409/4067

[6] Sumaryono and Sri Kusriyah, The Criminal Enforcement of the Fraud Mode of Multiple Money (Case study Decision No.61 / Pid.B / 2019 / PN.Blora) Jurnal Daulat Hukum: Volume 3 Issue 1, March 2020, url: http://jurnal.unissula.ac.id/index.php/RH/article/view/8811/4075

[7] Yati Sharfina Desiandri, Diversi Terhadap Anak yang Berkonflik dengan Hukum di Tingkat Penyidikan,USU Law Journal, Vol. 5 No. 1, January 2017

\section{Books}

[1] Dwidja Priyatno, Wajah Hukum Pidana Asas dan Perkembangan, Bekasi: Gramata Publishing, 2012

[2] Majelis Permusyawaratan Rakyat Indonesia, Undang-Undang Dasar Negara Republik Indonesia tahun 1945, Jakarta: Sekretariat Jenderal MPR RI, 2015

[3] R. Wiyono, Sistem Peradilan Pidana Anak di Indonesia, Jakarta: Sinar Grafika, 2016

[4] Soemitro, Metodologi Penelitian Hukum dan Jurimetri, Jakarta, Ghalia Indonesia, 1998

[5] Wagiati Soetedjo dan Melani, Hukum Pidana Anak, Bandung: Refika Adhitama, 2013 